Creative Commons User License: CC BY-NC-ND

Journal of Agricultural Extension

Abstracted by: EBSCOhost, Electronic Journals Service (EJS), Vol. 23 (4) October, 2019

Google Scholar, Journal Seek, Scientific Commons,

ISSN(e): 24086851; ISSN(Print); 1119944X

Food and Agricultural Organization (FAO), CABI and Scopus

http://journal.aesonnigeria.org

http://www.ajol.info/index.php/iae

http://eoi.citefactor.org/10.11226/v23i4

Email: editorinchief@aesonnigeria.org

\title{
Data Management Capabilities of Extension Personnel in Kaduna Agricultural Development Agency Kaduna State, Nigeria
}

https://dx.doi.org/10.4314/jae.v23i4.3

\author{
Abubakar, Lawal \\ Department of Vocational and Technical Education, \\ Ahmadu Bello University, Zaria. \\ E-mail: lawy 04@yahoo.co.uk; \\ Telephone: 08030629335 \\ Atala, Thomas Kakara \\ Department of Agricultural Extension and Rural Development, \\ Ahmadu Bello University, Zaria. \\ E-mail: atalatk@yahoo.com \\ Telephone: 08084708505
}

\section{Abdullahi, Hussaini Abdullahi}

Department of Vocational and Technical Education,

Ahmadu Bello University, Zaria.

E-mail: charanchihussy@gmail.com

Telephone: 07087712649

\author{
Abdullahi, Jamilu Alhaji \\ Department of Vocational and Technical Education, \\ Ahmadu Bello University, Zaria. \\ Telephone: 07067889461
}

\section{Abstract}

This study assessed the data management capabilities among extension personnel in Kaduna Agricultural Development Agency (KADA) in Kaduna State. Proportional and simple random sampling techniques were used to select 69 male and 28 female extension personnel to give a total sample size of 97 respondents. Data was collected using a structured questionnaire and analysed with descriptive statistics (means and percentages) and the Pearson Product Moment correlation analysis. The findings show that the majority of the respondents who were mostly educated to the level of diploma (73\%) agreed that knowledge of mathematics/statistics is the most important $(\bar{x}=7.83)$ requirement for data management. It was also revealed that adequate training and workshops are important requirements $(\bar{x}=7.60)$ for successful data management and enhance performance of staff particularly those involved in data collection as enumerators considering that the work is cumbersome. Pearson correlation analysis shows that there is link between educational qualification, job experience and training with level of understanding of the important aspects of data management. Proficiency in mathematics and statistics is the most important requirement for an effective data management as perceived by the KADA staff. 
Creative Commons User License: CC BY-NC-ND

Abstracted by: EBSCOhost, Electronic Journals Service (EJS),

Google Scholar, Journal Seek, Scientific Commons,

Food and Agricultural Organization (FAO), CABI and Scopus

http://eoi.citefactor.org/10.11226/v23i4
Journal of Agricultural Extension

Vol. 23 (4) October, 2019

ISSN(e): 24086851; ISSN(Print); $1119944 X$

http://journal.aesonnigeria.org

http://www.ajol.info/index.php/jae

Email: editorinchief@aesonnigeria.org

However, extension personnel performance can be improved through training and staff motivation through allowance and provision of transportation facilities. The Kaduna State ministry of agriculture in collaboration with KADA should be committed to ensuring the actualization of the above mentioned strategies.

Keywords: Data management, capabilities, extension personnel

\section{Introduction}

Data is unprocessed vital information that provides clear, objective, and numerical evidence on all aspects of our lives and the state of our country, including the growth and characteristics of our population, economic performance, levels of health and wellbeing and the condition of our surrounding environment (Sabrina and Priya, 2015: Williams, Bagwell, and Zosus, 2017). This information includes socio-economic and cultural set up of people being studied. Hence, the importance of data in all aspects of life can never be over emphasized and which must be managed properly for effective and enhanced extension staff capabilities.

Data management is the process by which observations and measurements of information are defined, documented and the methods by which the data from those observations are subsequently processed and maintained (Williams et al., 2017). Data management includes all processes from data collection to data dissemination. Agricultural data management in this regards encompass all the activities related to data handling on agriculture and food production. Successful data management entails users' possession of certain basic capabilities in terms of knowledge and skills that are necessary for effective data management in an agricultural setting (Abubakar and Abdullahi, 2012). Data management capabilities can be obtained and enhanced by training, provision of equipment, tools and facilities for extension job as well as staff motivation (Mesly, 2015).

Data exist as texts, audio, video, pictures and graphics. Data can also be in the form of images, words, figures, facts or ideas. The nature of data depends on the type of study job to be performed and the objectives to which the data is collected, while also the methods used indicates how the data can be collected and processed. In extension services, data management is one way in which agriculture data are handled from the initial process to the time when it is disseminated to farmers. This process, according to Ulrike, Maja, Andreas and Wolfgang (2017), covers a wide range of activities from simple data collection, processing, dissemination or sharing, security, curating, interlinking and to big data management services like remote sensing data used in precision agriculture (Yanbo, Chen, Tao, Huang and Xing-fa, 2018).

According to Mesly (2015), data management depend on many factors including education, training and experience. It involves a step by step activity of preparing and arranging the data in such a way that it becomes easier to understand interprete and utilize by the final user or audience. Extension personnel in KADA are expected to handle and manage data in 
Creative Commons User License: CC BY-NC-ND

Abstracted by: EBSCOhost, Electronic Journals Service (EJS),

Google Scholar, Journal Seek, Scientific Commons,

Food and Agricultural Organization (FAO), CABI and Scopus

http://eoi.citefactor.org/10.11226/v23i4
Journal of Agricultural Extension

Vol. 23 (4) October, 2019

ISSN(e): 24086851; ISSN(Print); $1119944 X$

http://journal.aesonnigeria.org

http://www.ajol.info/index.php/jae

Email: editorinchief@aesonnigeria.org

this way. However, report indicated that many of the extension staff possessed low level computer literacy which is one of the prerequisite knowledge for data handle. But the report show that they have high working experience which is an added advantage to data management capability. Similarly, the Kaduna State government supplied Information and Communication Technologies (ICTs) equipments to all agricultural zones in the State with the intension of providing capacity building for extension staff. Consequently, training of extension personnel through seminars and workshops were conducted with a view to achieving the goal of data management capabilities in the State. It is however not certain whether these efforts have yield positive result in the State.

Management of data has been a key issue in policy and decision making in all the sectors of development including agriculture. Hence, data management remains an indispensable tool for decision making in agricultural and rural development in Nigeria. However, a lot of challenges are met in relation to data integrity, adequacy and even security (Ulrike et al., 2017). These have tremendously hampered the decision making process leading to wrong or incorrect decisions made in respect to key developmental issues. As such there have been numerous outcries on data quality, handling and dissemination among extension workers which has been identified among others as an important factor affecting the integrity of data generated and used for the benefit of farmers. It is therefore necessary to assess the capabilities of personnel involved in data management for agriculture and rural development purposes in Kaduna state with a view for improving the capabilities in the key areas involved with respect to data collection, processing and dissemination.

The overall purpose of the study was to assess the data management capabilities among extension personnel in Kaduna Agricultural Development Agency (KADA) in Kaduna State. Specifically, the study:

- determined the perceptions of extension personnel on important requirements for data management; and

- assessed the relationships between the socio economic characteristics of extension personnel and their perceptions of the important requirements for data management.

\section{Methodology}

The study was carried out in Kaduna State of Nigeria. Kaduna state is located within the Latitude of $9^{\circ} 10^{\prime}-11^{\circ} 30^{\prime}$ North and Longitude of $6^{\circ}-9^{\circ} 10^{\prime}$ East, an estimated population of 8,252,366 projected for the 2006 National Population Census. Agricultural development projects are implemented in most cases through Kaduna Agricultural Development Agency (KADA). A preliminary survey revealed that there were 200 extension personnel in KADA, $70 \%$ (140) of which were males and $30 \%$ (60) females. To ensure a pair representation of the extension personnel based on sex, a proportional sampling procedure was used to select $50 \%$ of the respondents from each category. Hence, 70 males and 30 females were randomly selected using a table of random numbers obtained from KADA Monitoring and Evaluation (M\&E) unit to select the number of respondents for each group. A structured 
Creative Commons User License: CC BY-NC-ND

Abstracted by: EBSCOhost, Electronic Journals Service (EJS),

Google Scholar, Journal Seek, Scientific Commons,

Food and Agricultural Organization (FAO), CABI and Scopus

http://eoi.citefactor.org/10.11226/v23i4
Journal of Agricultural Extension

Vol. 23 (4) October, 2019

ISSN(e): 24086851; ISSN(Print); 1119944X

http://journal.aesonnigeria.org

http://www.ajol.info/index.php/jae

Email: editorinchief@aesonnigeria.org

questionnaire was used to collect data for the study. At the end of the data collection, a total of 97 useful questionnaire were returned excluding one from the male group and two from female group. Data were analyzed with descriptive statistics in the form of mean, frequencies and percentages in order to achieve a specific objective on the perceptions of the respondents about the important requirements for data management. Correlation coefficient was used to find the strength of relationships between the extension socioeconomic characteristics and their perceptions about important data management requirements.

The perception was represented as a weighted average based on a 3-point scale, from not important (1) to very important (3). The total scores for each respondent fall within the range of $10-30$ points from minimum to maximum. Using the weighted averages, any score of 3.33 or less represents not important; while a score from 3.34 to 6.66 indicates important; and mean score of 6.67 to 10.0 is rated as very important.

\section{Measurement of variables}

Sex: Dichotomous and measured as $1=$ male and $2=$ female.

Education: Ordinal and measured as the level of attainment of formal schooling of the extension personnel, categorized as $\mathrm{BSc} / \mathrm{HND}=$ high and ND/equivalent as medium and secondary/certificates as low.

Job experience: Number of years in tenure employment of the respondents

Training: Measured in the number of training(s) attended by the respondents at the time of data collection.

Perception: Represented by ten items on respondents' perceptions about important requirements for data management rated from $1=$ not important to $3=$ very important.

\section{Results and Discussions}

\section{Perceptions of Extension Personnel on Important Requirements for Data Management}

Table 1 shows the results of the respondents on the important requirements for successful data management. The finding shows that respondents with good understanding of mathematics and statistics had a mean score of $(\bar{x}=7.83)$; Trainings and workshops $(\bar{x}=$ 7.60) and good communication skills $(\bar{x}=7.18)$ which were perceived correctly to be most important requirements for data management. It implies that these items were considered prerequisites to a successful and effective data collection, processing and dissemination at the organizational and staff levels in KADA activities. The findings on the perceptions of respondents about the data management requirements are somehow expected especially those considered most important considering the fact that a lot of computational skills are required for data analysis in particular makes it highly imperative for the staff to possess adequate understanding of mathematics and statistics. On the operational efficiency and motivation to work successfully, it is obvious that trainings as well as attractive allowances are the much desired packages. The study findings of the requirements for data 
Creative Commons User License: CC BY-NC-ND

Abstracted by: EBSCOhost, Electronic Journals Service (EJS),

Google Scholar, Journal Seek, Scientific Commons,

Food and Agricultural Organization (FAO), CABI and Scopus

http://eoi.citefactor.org/10.11226/v23i4
Journal of Agricultural Extension

Vol. 23 (4) October, 2019

ISSN(e): 24086851; ISSN(Print); $1119944 X$

http://journal.aesonnigeria.org

http://www.ajol.info/index.php/jae

Email: editorinchief@aesonnigeria.org

management corroborate with those of Fadiji, Atala, Omokore, and Abdulsalam, (2013) on important requirements for the usage of information and communication technologies by extension agents.

Also, other items studied were provision of attractive allowances $(\bar{x}=6.40)$; Knowing how to use database software to find records, sort, review, edit, print and perform other functions $(\bar{x}$ $=6.28)$; availability of adequate transportation facilities $(\bar{x}=6.11)$ and Knowledge in ICTs $(\bar{x}$ $=6.55)$ were considered as important requirements for data collection and processing. While, adequate operational facilities (computing machines and software) $(\bar{x}=2.58$ ); familiarity with the data available to the user $(\bar{x}=2.95)$ and good human relations by staff $(\bar{x}$ = 3.23) were not regarded as requirements for data collection, processing and dissemination among the respondents. It has however been hypothesized in this study that the subconstructs in Table 1 are all very important requirements for data management. However, possession of human relations skills by staff, adequate operational facilities and Knowledge in ICTs not being important for data management according to the respondents has some implications. The fact there is need for more training to improve skills and further motivate the staff indicates low appreciation of the value of human relations skills in data management process. Knowledge in ICTs is highly demanding especially for data analysts. The respondents being mostly participating in field level data management process specifically in data collection considering their educational level of mostly OND certificates holders may be unlikely to be involved in the process that requires use of ICTs i.e. data analysis and interpretation. Hence, the respondents might not see any rationale for using the ICT gadgets in their works. This finding agrees with the one reported by Gyata and Abdullahi (2012) who opined that knowledge in ICT, cost of ICT equipments and awareness were the major obstacle to data management.

Table 1: Important requirements for data management

Sub-constructs of requirements for successful data management (collection, processing and dissemination)

Mean

Perceptions

Good communication skills of staff

Knowledge in ICTs

Good understanding of mathematics and statistics

Familiarity with the data available to the user

Knowing how to use database software to find records, sort, review, edit,

print and perform other functions.

Provision of attractive allowances.

Availability of adequate transportation facilities

Adequate operational facilities (computing machines and software).

Trainings and workshops

Good human relations by data management staff

**Very important * Important 
Creative Commons User License: CC BY-NC-ND

Abstracted by: EBSCOhost, Electronic Journals Service (EJS),

Google Scholar, Journal Seek, Scientific Commons,

Food and Agricultural Organization (FAO), CABI and Scopus

http://eoi.citefactor.org/10.11226/v23i4
Journal of Agricultural Extension

Vol. 23 (4) October, 2019

ISSN(e): 24086851; ISSN(Print); 1119944X

http://journal.aesonnigeria.org

http://www.ajol.info/index.php/jae

Email: editorinchief@aesonnigeria.org

\section{Relationships between Extension Personnel Socio-Economic Characteristics and Data Management Requirements}

Table 2 shows that there is moderate relationship between the extension personnel characteristics and their perception of data management requirements. The result shows that age $(r=0.57)$ of the respondents was observed to be an important factor as data management requirement of extension personnel. The study findings further indicated that training and experience $(r=0.89$ and $r=0.64$ respectively) of extension personnel are related to data management. This result implies that trained extension personnel were more in agreement with the requirements for data management as they are more likely to have participated in various research trainings, data collection, processing and dissemination more than the untrained personnel. Furthermore, the finding indicated that the relationship between the perceived data management requirement with both training and job experience of the respondents were positively strong. This means that the higher the level of training extension personnel received and their experience on the job, the more likelihood of the extension personnel to increase their level of expertise in data collection, processing, utilization and dissemination. This finding is in agreement with that of Sanusi (2016), who reported positive and strong relationship between years of experience, education and awareness level of extension personnel.

Table 2 further shows the correlation co-efficient ( $r$ ) for education was 0.67 . This indicates positive but strong relationship, relationship between education and the perceptions of extension personnel on important data management requirement. The implication of the finding is that education is linked to predisposition of the extension personnel to accept the fact that data management requirements are important. Education is an important variable for effective extension service delivery and increase staff occupational activeness and level of commitment to duties with respect to ICT compliance (Abdullahi, Mlozi and Nzalayaimisi, 2015; Abubakar and Abdullahi, 2012).

Table 2: Correlation of extension personnel socio-economic characteristics and data management requirements

\begin{tabular}{lc} 
Variables & Pearson correlation \\
\hline Sex & $0.57^{*}$ \\
Age & $0.73^{*}$ \\
Training & $0.89^{\star}$ \\
Job experience & $0.64^{*}$ \\
Education & $0.67^{\star}$ \\
\hline
\end{tabular}

${ }^{*} \mathrm{P} \leq 0.05$

\section{Conclusion and Recommendations}

Possession of training, education and job experience including having numeracy skills (understanding mathematics and statistics) are the most important requirement for an effective data management. Training, education and experience were found to be positively and statistically related to data management requirements of extension personnel in Kaduna 
Creative Commons User License: CC BY-NC-ND

Abstracted by: EBSCOhost, Electronic Journals Service (EJS),

Google Scholar, Journal Seek, Scientific Commons,

Food and Agricultural Organization (FAO), CABI and Scopus

http://eoi.citefactor.org/10.11226/v23i4
Journal of Agricultural Extension

Vol. 23 (4) October, 2019

ISSN(e): 24086851; ISSN(Print); $1119944 X$

http://journal.aesonnigeria.org

http://www.ajol.info/index.php/jae

Email: editorinchief@aesonnigeria.org

State. This result implies that trained extension personnel were more in agreement with the requirements for data management as they are more likely to have participated in various research trainings, data collection, processing and dissemination more than the untrained personnel. Similarly, the higher the level of education and the training extension personnel received coupled with their experience on the job, the more likelihood of the extension personnel to increase their level of expertise in data collection, processing, utilization and dissemination. Hence, performance in data management can be improved through educational training and re-training especially in numeracy and statistics, ICTs, human relations and communication skills in addition to increasing staff motivation through allowance and transportation facilities. The Kaduna State government through the ministry of agriculture in collaboration with KADA should be committed to ensuring that the combination of the above mentioned is provided adequately to achieve effective data management goal in Kaduna State.

\section{References}

Abdullahi, H.A., Mlozi, M.R.S. and G.K. Nzalayaimisi (2015). Determinants of students' academic achievement in agricultural sciences. A case study of secondary schools in Katsina state, Nigeria. African Educational Research Journal, vol. 3 (1):80-88.

Abubakar, L. and Abdullahi, H. A. (2012). The Role of information and communication technologies in poverty alleviation and food security in Nigeria. Journal of Vocational Studies Vol. 6 (1).

Denso, D. Mamo, Y. And Jema, H. (2014). Analyzing socio-economic factors affecting the use of ICT among farmers in central high lands of Ethiopia. African journal of Agricultural Science and Technology 2(8) Pp163-171.

Fadiji, T.O., Atala T.K., Omokore, D.F. and Abdulsalam, Z. (2013). Village extension agents socioeconomic characteristics in usage of ICT: A study of three North-West States in Nigeria. American journal of science and technology, 1(3) Pp82-88.

Ganiyu, H.A. (2015). Factors affecting adoption of forest conservation practices in Kajama Local Government Area of Kwara State, Nigeria. M.S. Thesis Department of Agricultural Economics and Rural Sociology, Ahmadu Bello University, Zaria.

Gyata, B.A., and Abdullahi M.K. (2012). Problems associated with the use of internet facilities in Benue State. Journal of Agricultural Extension 1(2) Pp203-212.

Mesly, O. (2015). Creating Models in Psychological Research. États-Unis: Springer Psychology: 126 pages. ISBN 978-3-319-15752-8

Morakinyo, O.M., Adebowale S.A. and Oloruntoba E.O (2015). Wealth status and sex differential of household heads: Implication for source of drinking water in Nigeria. Journal of the Belgian Public Health Association 73:58 https://doi.org/10.1186/s13690-015-01059

Sabrina, K. and Priya N. (2015). Lowering data dimensionality in big data for the benefit of precision agriculture. Procedia Computer Science, 48, 548-554. 
Creative Commons User License: CC BY-NC-ND

Abstracted by: EBSCOhost, Electronic Journals Service (EJS),

Google Scholar, Journal Seek, Scientific Commons,

Food and Agricultural Organization (FAO), CABI and Scopus

http://eoi.citefactor.org/10.11226/v23i4
Journal of Agricultural Extension

Vol. 23 (4) October, 2019

ISSN(e): 24086851; ISSN(Print); 1119944X

http://journal.aesonnigeria.org

http://www.ajol.info/index.php/jae

Email: editorinchief@aesonnigeria.org

Sanusi, M.K., Tijjani, S.A. and Akinsokeji O.A. (2016). Level of utilization of modern processing technologies among Shea butter processors in Kwara State, Nigeria. Nigerian Journal of Rural Sociology 16(4) Pp39-45.

Ulrike, W., Maja R., Andreas W. and Wolfgang, M. (2017). Data management and data enrichment for systems biology project. Journal of Biotechnology 261: 229-237.

Williams, M., Bagwell, J. and Nahm Zosus, M. (2017). Data management plans: the missing perspective. Journal of Biomedical Informatics 71: 130-142.

Yakubu, D.H. (2013). Socio-economic factors affecting the adoption of ICT by extension workers in the North-West, zone of Nigeria, 1(9) Pp255-269.

Yanbo, H., Chen, Z., Tao, Y. U., Huang, X. and Xing-fa, G. U. (2018). Agricultural remote sensing big data: Management and applications. Journal of Integrative Agriculture 2018, 17(9): 1915-1931 